\title{
EVALUASI KONDISI PENCAHAYAAN INTEGRASI MANUAL PADA RUANG KANTOR MENARA BALAIKOTA MAKASSAR
}

\author{
Irnawaty Idrus \\ Universitas Muhammadiyah Makassar \\ irnawatyiqbal@yahoo.co.id
}

\begin{abstract}
ABSTRAK
Konsep bangunan dengan efisiensi energi sangat penting karena jika melihat penggunaan energi secara global, sektor bangunan sendiri menyerap $45 \%$ dari kebutuhan energi secara global. Salah satu metode dalam arsitektur hemat energi yaitu mengoptimasikan sistem tata cahaya, integrasi antara sistem tata cahaya buatan-alamiah serta sinergi antara metode pasif dan aktif baik secara manual ataupun otomatis.

Selain itu untuk memenuhi tuntutan fungsi sebagai tempat pelayanan kepada masyarakat maka dibutuhkan perkantoran pemerintah yang nyaman, dimana kenyamanan bisa dicapai dengan memperhatikan factor pencahayaan pada ruang yang akan berpengaruh terhadap phisik dan psikis. Penelitian ini bertujuan untuk mengetahui kualitas pencahayaan alami dan buatan yang dikombinasikan secara manual sesuai dengan keadaan eksisting pada ruang kantor pada tiga kondisi langit yaitu cerah, berawan dan mendung. Lokasi penelitian di menara Balaikota Makassar. Sampel penelitian dipilih secara purposive sampling dan dipilih lantai lima sebagai lokasi penelitian. Pengumpulan data dilakukan bertahap, yaitu pengamatan awal, pengukuran dan pencatatan di lapangan, pengukuran pencahayaan eksisting, dan kemudian melakukan simulasi pencahayaan dengan software DiaLux 10.1. Hasil penelitian menunjukkan pada kondisi langit cerah dan berawan, rata-rata kualitas pencahayaan integrasi sudah hampir memenuhi standar ketentuan pencahayaan minimum. Pada kondisi langit mendung kualitas pencahayaan rata-rata masih dibawah standar.
\end{abstract}

Kata kunci: Pencahayaan Integrasi, Ruang Kantor, Simulasi Pencahayaan

\section{PENDAHULUAN}

Indonesia merupakan daerah yang beriklim tropis lembab dengan memiliki spesifikasi intensitas radiasi matahari yang kuat, temperatur udara yang relatif tinggi, kelembaban udara yang tinggi, serta keadaan langit yang selalu berawan dimana faktor-faktor ini selalu terjadi hampir sepanjang tahun. Faktor-faktor ini tentu sangat berpengaruh pada kondisi lingkungan thermis dan pencahayaan alami, yang sangat berkaitan dengan tingkat kenyamanan manusia (Sukawi, 2013). Faktor kenyamanan terhadap pencahayaaan dalam ruang perkantoran meliputi cahaya yang mencukupi standar minimum yang disyaratkan dan tidak menyilaukan mata. Kurangnya tingkat pencahayaan dalam ruang kerja akan menimbulkan astenopia dan akan menimbulkan kelelahan pada mata serta mengurangi kecepatan dan efisiensi membaca. Selain itu kepadatan cahaya dapat mempengaruhi kinerja dan kenyamanan visual; pencahayaan yang tidak merata tidak memuaskan secara subjektif (Kristanto, 2004). Jika lingkungan penerangan ruang tergolong buruk, dapat menyebabkan ketidakpuasan pekerja, menurunkan produktivitas kerja, dan tidak baik untuk kesehatan visual (Nurdiah, 2007).

Terdapat dua jenis sumber cahaya yang dapat dipergunakan untuk penerangan di dalam ruang, yaitu cahaya alam yang berasal dari kubah langit dan cahaya buatan dari pencahayaan elektrik. Penerangan alam berperan penting dalam pembangunan berkelanjutan (sustainable development) karena dapat dimanfaatkan tanpa membutuhkan energi dan tidak menimbulkan polusi sehingga mengurangi polutan (Evans, 1981). Ketersediaan cahaya matahari yang melimpah merupakan suatu kelebihan tersendiri bagi bangunan-bangunan di lingkungan tropis. Intensitas penerangan alam di daerah khatulistiwa dapat mencapai \pm 10.000 lux dan tersedia sepanjang tahun dengan intensitas yang dipengaruhi kubah langit. Lama waktu penyinaran matahari relatif stabil sepanjang tahun yaitu antara pukul 06.00-18.00 atau antara 11-12 jam (Koenigsberger, 1974). Bangunan yang telah dirancang agar memiliki cahaya alami penuh, tetap membutuhkan 
sistem pencahayaan elektrik sebagai pendukung. Pada saat cahaya alami tidak dapat memenuhi standar kebutuhan cahaya pada ruang, pada saat itu pula dibutuhkan pencahayaan buatan untuk memenuhinya (Karlen, 2004). Hasil Penelitian dari Belinda (2011) tentang karakteristik pencahayaan yaitu iluminasi meningkat saat cerah dan menurun saat mendung.

Dengan kemajuan teknologi, memberikan peluang dalam menganalisis pencahayaan menggunakan komputer. Program Dialux 10.1 dapat mengidentifikasi nilai cahaya siang dan cahaya artificial (lampu) secara cepat dan tepat. Simulasi pencahayaan dalam bangunan dapat dibuat sesuai dengan parameter di lapangan dan lingkungan objek, dengan hasil pengukuran berupa angka, grafik, dan gambar.

Pemilihan lokasi penelitian sebagai studi kasus yaitu Menara Balaikota Makassar, yang berdasarkan pengamatan awal peneliti bahwa kualitas pencahayaan alaminya kurang baik. Penelitian ini ingin mengetahui kualitas pencahayaan integrasi pada ruang kerja di Menara Balaikota Makassar pada tiga kondisi cahaya langit (cerah, berawan, mendung) sebagai upaya optimalisasi pencahayaan alami dan upaya penghematan energi yang diaplikasikan manual dengan mengintegrasikan pencahayaan alami dan buatan dengan menyalakan lampu secara seling-seling.

\section{METODE PENELITIAN}

Penelitian ini dilakukan di lantai lima Menara Balaikota Makassar. Jenis penelitian yang dilakukan yaitu deskriptif kuantitatif dengan metode modelling/ permodelan.

Data yang akan diteliti bersumber dari data primer dan data sekunder. Data primer adalah data yang diperoleh dari pengukuran langsung di lapangan serta dengan simulasi komputer. Sedangkan data sekunder adalah data yang diperoleh dari dokumen-dokumen dan referensi yang di anggap relevan dengan masalah yang diteliti. Dalam penelitian ini, jenis data yang dibutuhkan disesuaikan dengan variabel pencahayaan yang digunakan.

\section{Instrumen Pengumpulan Data}

Berikut adalah alat-alat yang dipergunakan dalam penelitian: (a) Luxmeter digital, (b) Meteran, (c) Alat tulis untuk mencatat data hasil pengukuran, (d) Kamera digital, (e) Laptop, untuk mengolah data dan simulasi pencahayaan. Adapun software yang dipakai dalam simulasi komputer untuk menganalisis pencahayaan yaitu DIALux 10.1.

Pengukuran dilakukan untuk dua sistem pencahayaan, yaitu pencahayaan alami dan pencahayaan buatan. Adapun metode penempatan titik ukur, dilakukan mengikuti ketentuan SNI. Waktu pengukuran pencahayaan alami, dilakukan pada pagi (pukul 09.00), siang (pukul 12.00) dan sore (pukul 15.00). Alat ukur diletakkan setinggi $0,75 \mathrm{~m}$ di atas permukaan lantai, dengan pertimbangan bahwa bidang kerja horizontal setinggi meja kerja. Jarak alat ukur satu dan lainnya adalah tiga meter, TUS (Titik Ukur Samping) berjarak 1/3d dari dinding bukaan, dan TUU (Titik Ukur Utama) berada pada pertengahan ruangan (SNI 03-2396-2001). Mengingat kondisi langit yang sangat bervariasi, pengukuran dilaksanakan pada tiga kondisi langit yaitu langit cerah (clear sky), berawan (intermediate sky) dan mendung (overcast sky). Besarnya prosentase cloud cover dilihat berdasarkan pengamatan langsung terhadap keberadaan awan pada langit dengan ketentuan cloud cover pada langit cerah yaitu tidak lebih dari 30\%, langit berawan 30-80\% dan langit mendung diatas $80 \%$ (Baharuddin, 2009).

Data yang harus dimasukkan untuk dapat melakukan simulasi meliputi model tiga dimensi, kondisi langit, waktu pengukuran (bulan, tanggal dan jam), data lokasi, zona yang disimulasikan, orientasi, titik referensi atau grid referensi sebagai posisi titik ukur dan kamera sebagai titik acuan dalam menampilkan hasil pencahayaan secara meruang. Untuk model simulasi, pertama-tama membentuk gambar tiga dimensi objek yang akan diteliti sesuai kondisi riil pada program DIALUX 10.1. dengan penyederhanaaan bentuk dan elemen bangunan untuk memudahkan running program simulasi. Setelah semua data variabel dimasukkan, kemudian dilakukan "calculate" terhadap kualitas pencahayaan. 


\section{Metode Analisis Data}

Teknik analisis yang digunakan dalam penelitian ini adalah analisis data Statistik Deskriptif Kuantitatif. Analisis data jenis ini biasa juga disebut dengan analisis Univariat, yang terdiri dari Distribusi, Tendensi Sentral dan Dispersi. Distribusi merupakan rangkuman frekuensi dari nilai individual atau rentang nilai untuk variabel. Tendensi Sentral adalah sebuah perkiraan dari nilai distribusi, misalnya Rata-rata (Mean), Median, Modus. Dispersi merujuk pada sebaran nilai atau harga di sekitar tendensi sentral (Widi, 2010).

\section{HASIL DAN PEMBAHASAN}

Pengukuran tingkat pencahayaan dilakukan per zona ruang untuk memudahkan peneliti dalam menganalisis (Gambar 1). Keseluruhan terdapat 6 (enam) zona yang diteliti. Pencahayaan Alami bersumber dari cahaya matahari yang masuk melalui jendela, dan pencahayaan buatan bersumber pada lampu yang dinyalakan secara selang seling sesuai dengan eksisting. Metode integrasi manual

Secara geografis Kota Metropolitan Makassar terletak di pesisir pantai barat Sulawesi Selatan pada koordinat 119 $18^{\prime} 27,97^{\prime \prime}$ - 119³2'31,03" Bujur Timur dan 500'30,18" 5014'6,49" Lintang Selatan (Makassar dalam Angka, 2010). Lokasi yang diinput ke dalam program simulasi yaitu Makassar, dengan Longitude $119,40^{\circ}$ dan Latitude $-5,10^{\circ}$.

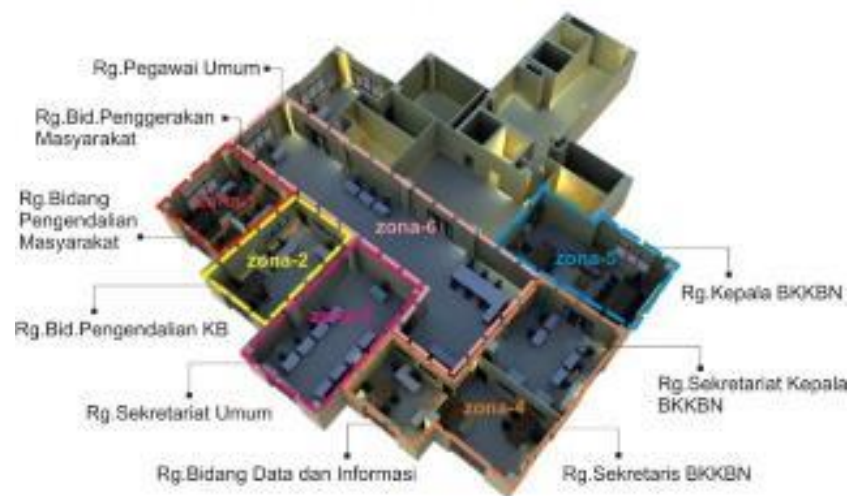

Gambar 1. Zona Pencahayaan Objek Penelitian

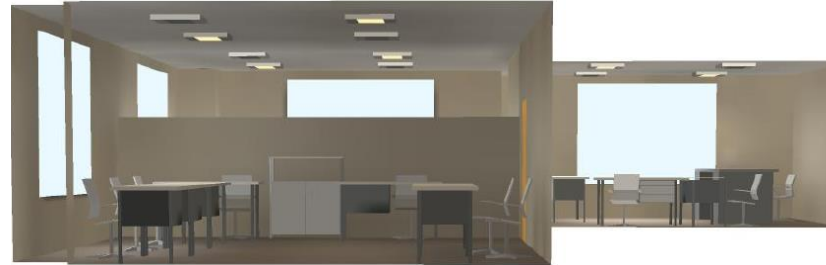

Gambar 2. Contoh lampu yang dinyalakan secara selang-seling pada Zona-4

\section{Analisis Hasil Penelitian Pencahayaan Integrasi Zona-1}

Tabel 1. Data pengukuran zona-1

\begin{tabular}{|c|c|c|c|c|c|}
\hline \multirow{2}{*}{ NO. } & \multirow{2}{*}{ WAKTU } & \multicolumn{3}{|c|}{ NILAI ILUMINASI (LUX) } & \multirow[t]{2}{*}{$\begin{array}{l}\text { KONDISI } \\
\text { LANGIT }\end{array}$} \\
\hline & & Emin & Emax & Eavg & \\
\hline \multirow{4}{*}{1} & & 84 & 640 & 343 & CERAH \\
\hline & 09.00 & 95 & 707 & 410 & BERAWAN \\
\hline & & 45 & 385 & 226 & MENDUNG \\
\hline & & 80 & 440 & 290 & CERAH \\
\hline \multirow[t]{3}{*}{2} & 12.00 & 68 & 467 & 307 & BERAWAN \\
\hline & & 52 & 431 & 255 & MENDUNG \\
\hline & & 47 & 376 & 225 & CERAH \\
\hline \multirow[t]{2}{*}{3} & 15.00 & 59 & 410 & 271 & BERAWAN \\
\hline & & 45 & 384 & 225 & MENDUNG \\
\hline
\end{tabular}

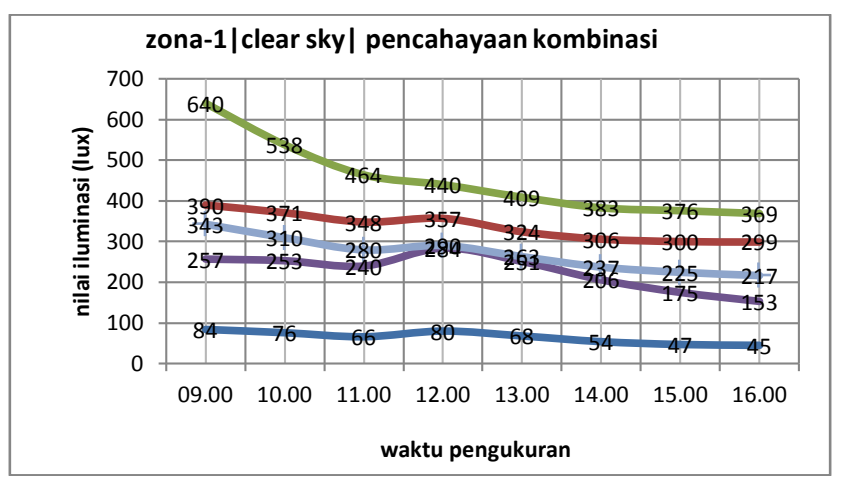

Gambar 3. Grafik Simulasi Pencahayaan Zona-1 pada Cuaca Cerah

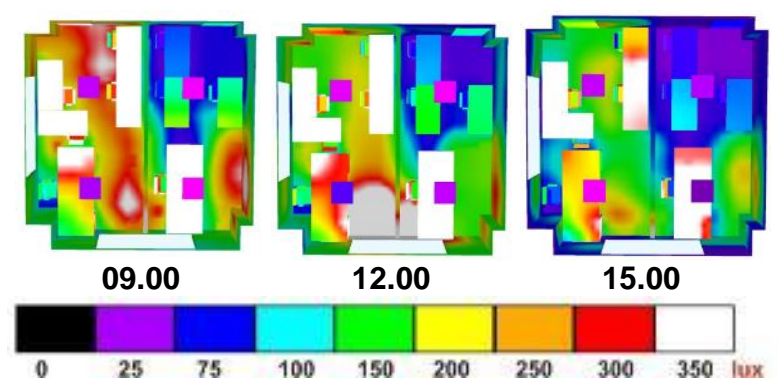

Gambar 4. False Colour Rendering Simulasi Dialux 10.1 Zona 1 Clear Sky 
Hasil simulasi memperlihatkan bahwa Tingkat pencahayaan kombinasi manual pada Zona-1 Sabtu tgl. 20 April 2013 kondisi langit cerah, belum memenuhi standarisasi. Dikarenakan iluminasi rata-rata (Eavg) berkisar 217-343 Lux, dibawah standar lluminasi ruang Kerja 350 Lux.

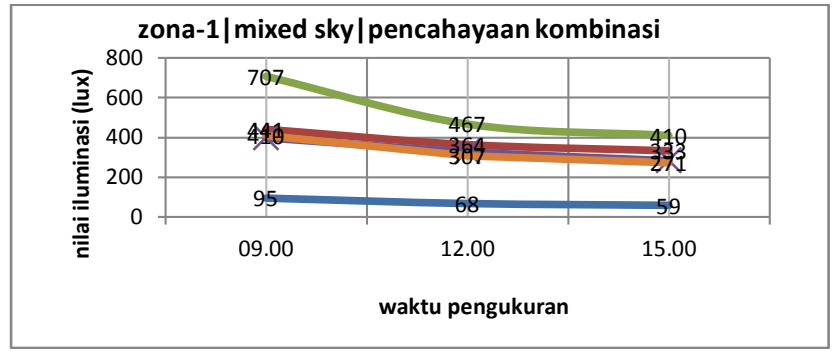

Gambar 5. Grafik Simulasi Pencahayaan Zona-1 pada Cuaca Berawan

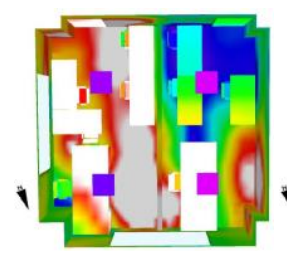

09.00

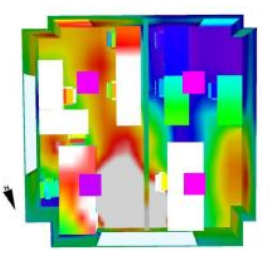

12.00

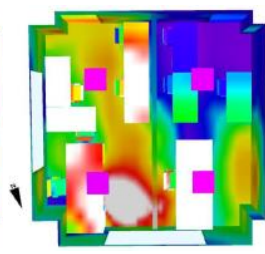

15.00

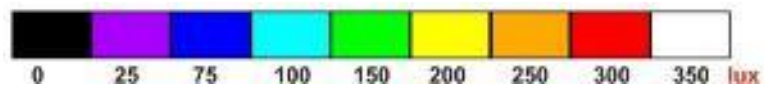

Gambar 6. False Colour Rendering Simulasi Dialux 10.1 Zona 1 Mixed Sky

Hasil simulasi memperlihatkan bahwa Tingkat pencahayaan kombinasi manual pada Zona-1 Rabu tgl. 08 Mei 2013 kondisi langit berawan memenuhi standarisasi pada pagi hari, dikarenakan iluminasi rata-rata (Eavg) mencapai 410 Lux, tetapi menurun ketika siang dan sore hari, hanya berkisar 271-307 Lux.

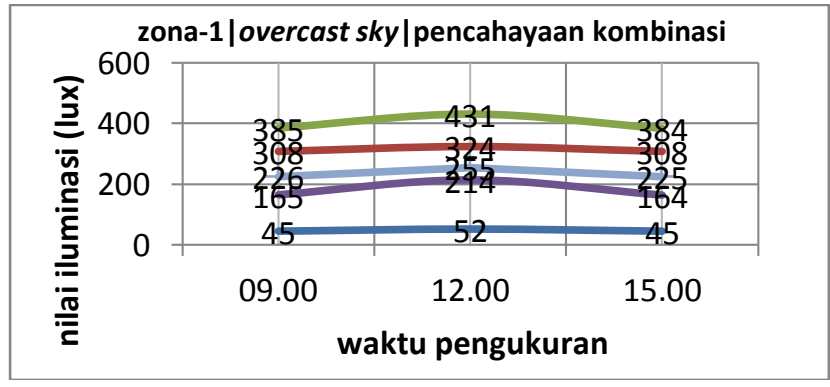

Gambar 7. Grafik Simulasi Pencahayaan Zona-1 pada Cuaca Mendung
Hasil simulasi memperlihatkan bahwa Tingkat pencahayaan kombinasi manual pada Zona-1 hari Rabu tgl. 08 Mei 2013 dengan kondisi langit mendung belum memenuhi standarisasi, iluminasi rata-ratanya (Eavg) hanya berkisar 225-255 Lux.

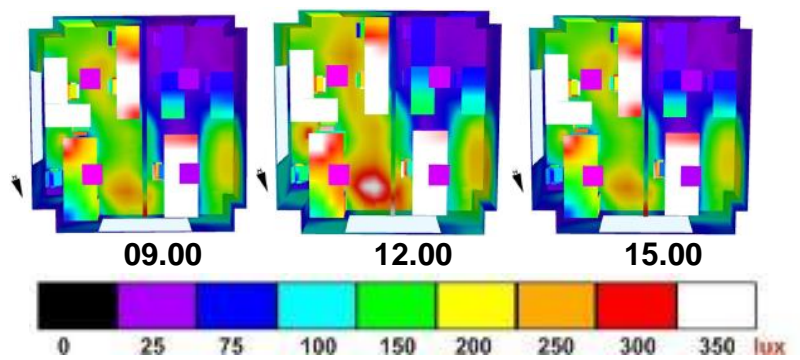

Gambar 8. False Colour Rendering Simulasi Dialux 10.1 Zona 1 Overcast Sky

\section{Pencahayaan Integrasi Zona-2}

Tabel 2. Data pengukuran zona-2

\begin{tabular}{cccccl}
\hline \multirow{2}{*}{ NO. } & \multirow{2}{*}{ WAKTU } & \multicolumn{3}{c}{ NILAI ILUMINASI (LUX) } & \multicolumn{1}{c}{$\begin{array}{l}\text { KONDISI } \\
\text { LANGIT }\end{array}$} \\
\cline { 3 - 6 } & & Emin & Emax & Eavg & \\
\hline \multirow{3}{*}{1} & \multirow{2}{*}{09.00} & 132 & 1005 & 418 & CERAH \\
& & 764 & 1590 & 549 & BERAWAN \\
& & 91 & 590 & 266 & MENDUNG \\
2 & \multirow{2}{*}{12.00} & 134 & 1252 & 450 & BERAWAN \\
& & 89 & 740 & 308 & MENDUNG \\
& & 99 & 685 & 321 & CERAH \\
3 & \multirow{2}{*}{15.00} & 121 & 1086 & 419 & BERAWAN \\
& & 76 & 587 & 265 & MENDUNG \\
\hline
\end{tabular}

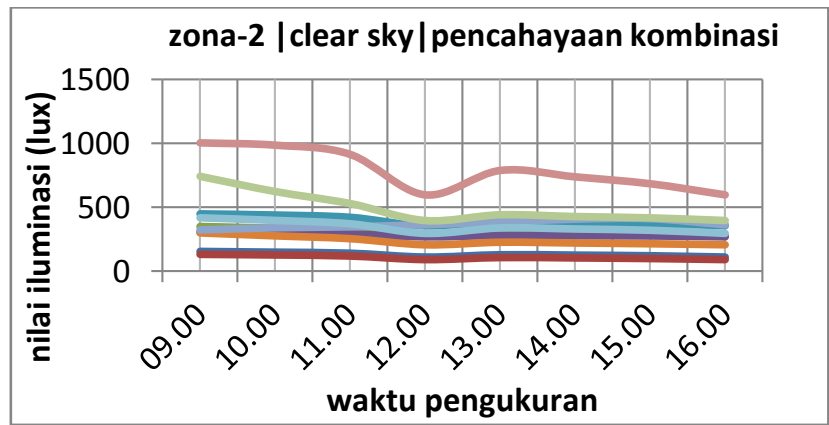

Gambar 9. Grafik Simulasi Pencahayaan Zona-2 pada Cuaca Cerah

Hasil simulasi memperlihatkan bahwa Tingkat pencahayaan kombinasi pada Zona-2 hari Sabtu tgl. 20 April 2013 dengan kondisi langit 
cerah memenuhi standarisasi pada pagi hari, iluminasi rata-ratanya (Eavg) berkisar 418 Lux. Tetapi pada siang dan sore hari belum memenuhi standarisasi, kemudian dari hasil render dapat terlihat penyebaran cahaya yang tidak merata keseluruh ruang.

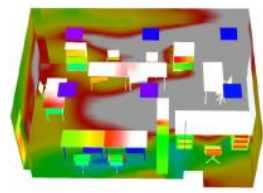

09.00

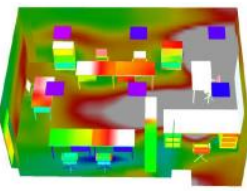

12.00

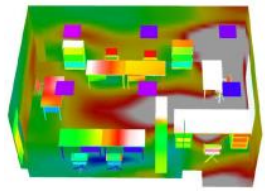

15.00

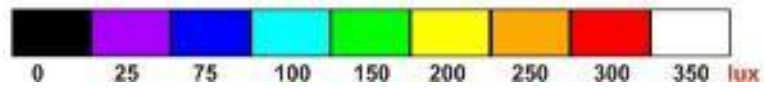

Gambar 10. False Colour Rendering Simulasi Dialux 10.1 Zona 2 Clear Sky

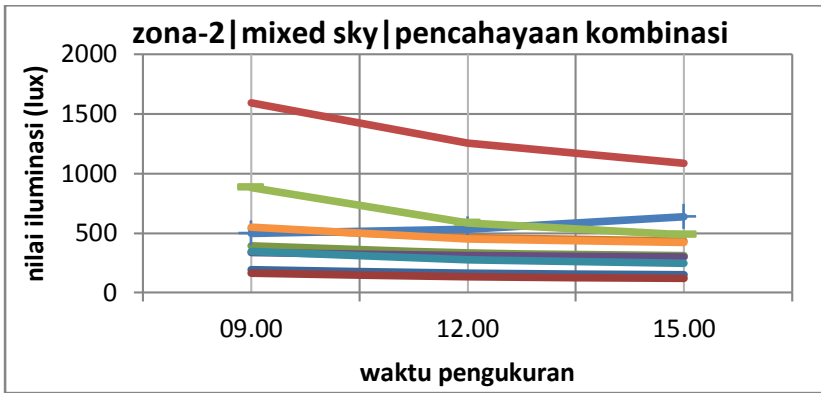

Gambar 11. Grafik Simulasi Pencahayaan Zona-2 pada Cuaca Berawan

Hasil simulasi memperlihatkan bahwa Tingkat pencahayaan integrasi eksisting pada Zona-2 hari Minggu tgl. 26 Mei 2013 dengan kondisi langit Berawan memenuhi standarisasi, dikarenakan iluminasi rata-rata (Eavg) berkisar 419-549 Lux, yang berarti jauh diatas standar lluminasi ruang Kerja yaitu 350 Lux, tetapi dapat dilihat penyebaran cahaya yang tidak merata keseluruh ruang.

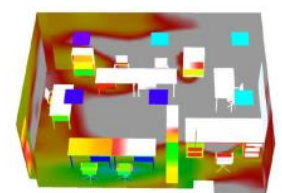

09.00

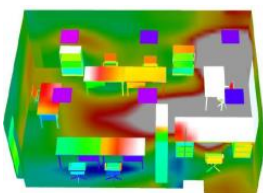

12.00

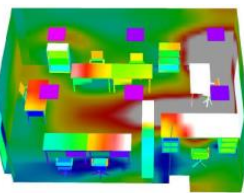

15.00

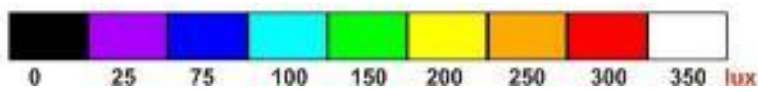

Gambar 12. False Colour Rendering Simulasi Dialux 10.1 Zona 2 Mixed Sky

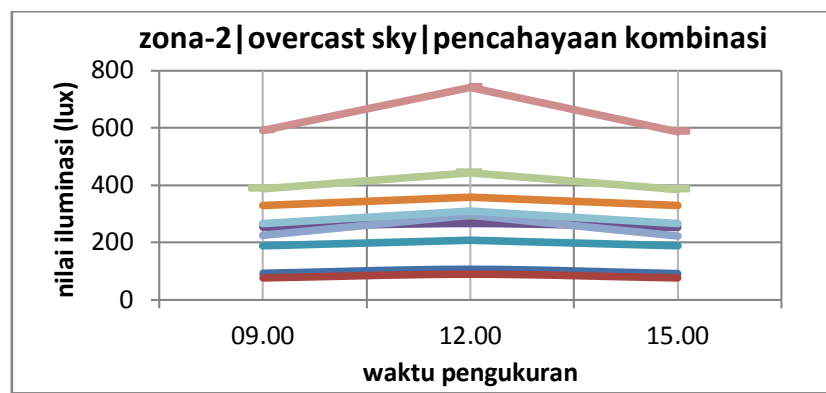

Gambar 13. Grafik Simulasi Pencahayaan Zona-2 pada Cuaca Mendung
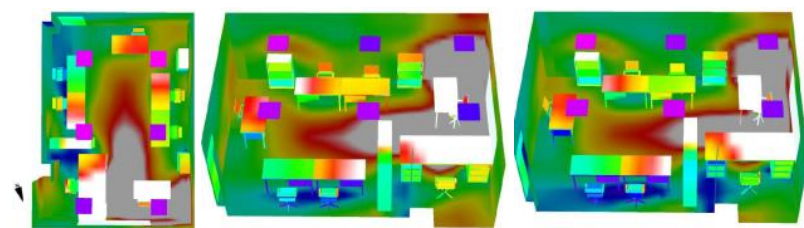

09.00

12.00

15.00

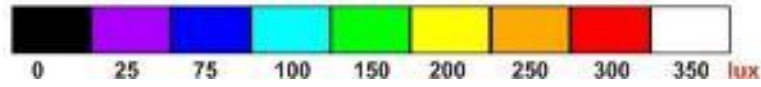

Gambar 14. False Colour Rendering Simulasi Dialux 10.1 Zona 2 Overcast Sky

Hasil simulasi memperlihatkan bahwa tingkat pencahayaan kombinasi manual pada zona-2 hari rabu tgl. 8 mei 2013 dengan kondisi langit mendung, belum memenuhi standar, Eavg hanya berkisar 265-308 lux.

\section{Pencahayaan Integrasi Zona-3}

Tabel 3. Data pengukuran zona-3

\begin{tabular}{|c|c|c|c|c|c|}
\hline \multirow[t]{2}{*}{ NO. } & \multirow{2}{*}{ WAKTU } & \multicolumn{3}{|c|}{ NILAI ILUMINASI (LUX) } & \multirow[t]{2}{*}{$\begin{array}{l}\text { KONDISI } \\
\text { LANGIT }\end{array}$} \\
\hline & & Emin & Emax & Eavg & \\
\hline \multirow{4}{*}{1} & & 84 & 334 & 233 & CERAH \\
\hline & 09.00 & 70 & 302 & 210 & BERAWAN \\
\hline & & 63 & 294 & 199 & MENDUNG \\
\hline & & 91 & 598 & 297 & CERAH \\
\hline \multirow[t]{3}{*}{2} & 12.00 & 82 & 380 & 240 & BERAWAN \\
\hline & & 76 & 344 & 228 & MENDUNG \\
\hline & & 99 & 685 & 321 & CERAH \\
\hline \multirow[t]{2}{*}{3} & 15.00 & 55 & 288 & 189 & BERAWAN \\
\hline & & 48 & 280 & 174 & MENDUNG \\
\hline
\end{tabular}




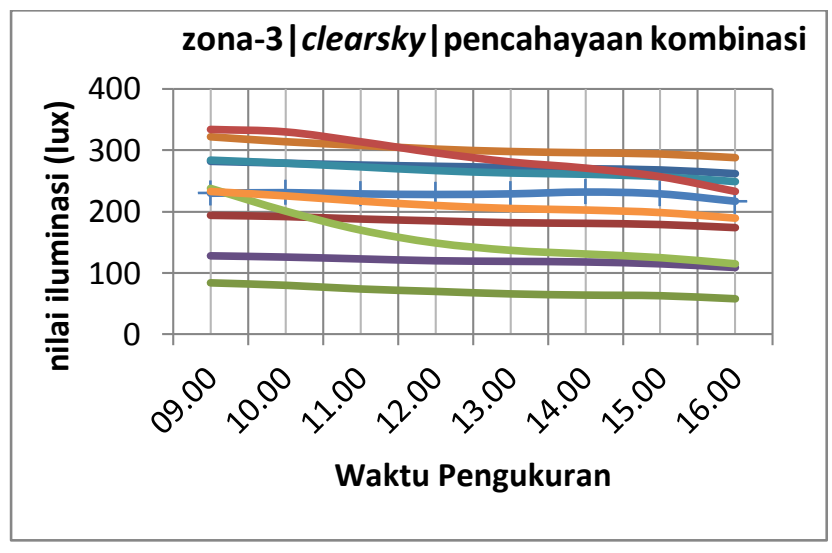

Gambar 15. Grafik Simulasi Pencahayaan Zona-3 pada Cuaca Cerah

Hasil simulasi memperlihatkan bahwa Tingkat pencahayaan kombinasi manual pada Zona-3 hari Sabtu tgl. 20 April 2013 dengan kondisi langit Cerah belum memenuhi standarisasi, iluminasi rata-rata (Eavg) hanya berkisar 199233 Lux.

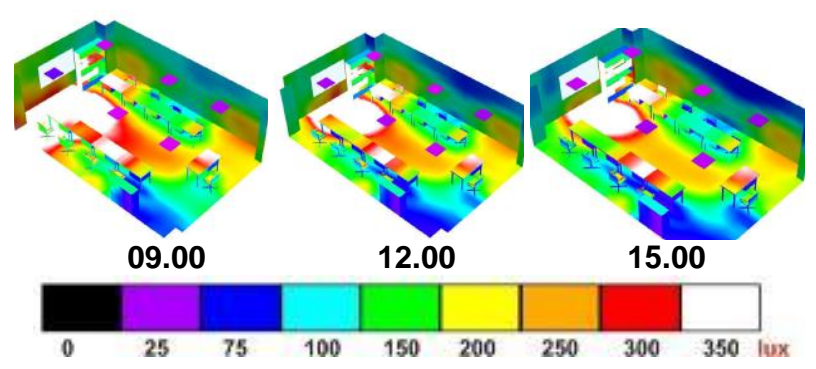

Gambar 16. False Colour Rendering Simulasi Dialux 10.1 Zona 3 Clear Sky

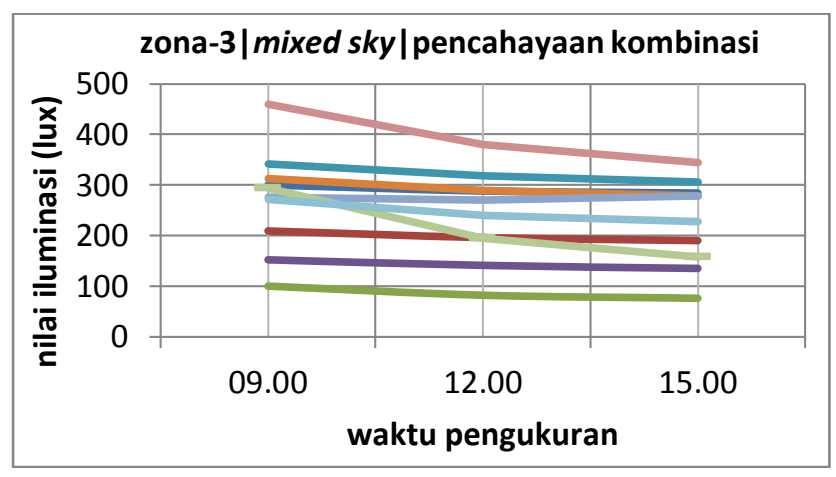

Gambar 17. Grafik Simulasi Pencahayaan Zona-3 pada Cuaca Berawan

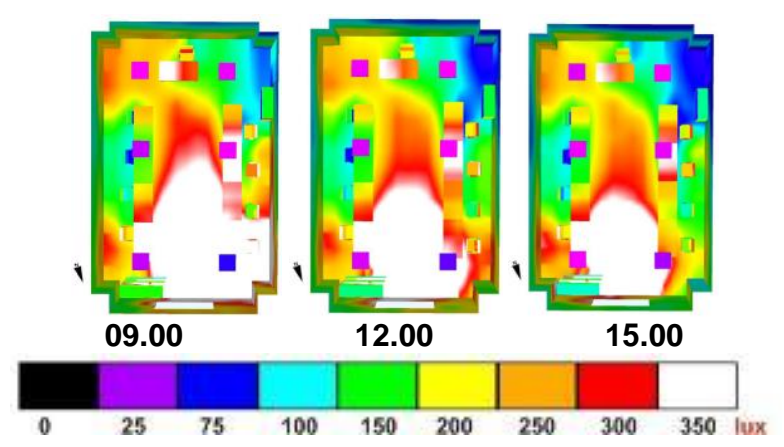

Gambar 18. False Colour Rendering Simulasi Dialux 10.1 Zona 3 Mixed Sky

Hasil simulasi memperlihatkan bahwa Tingkat pencahayaan integrasi eksisting pada Zona-3 hari Minggu tgl. 26 Mei 2013 dengan kondisi langit berawan belum memenuhi standarisasi, iluminasi rata-rata (Eavg) berkisar 228-272 Lux, yang berarti dibawah standar Iluminasi ruang Kerja 350 Lux.

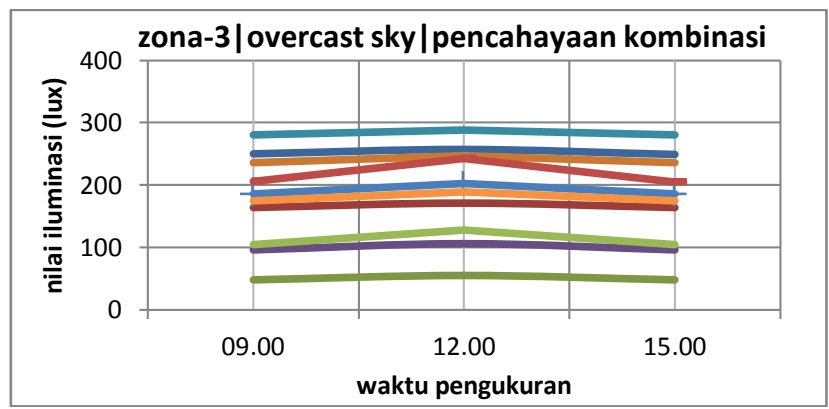

Gambar 19. Grafik Simulasi Pencahayaan Zona-3 pada Cuaca Mendung

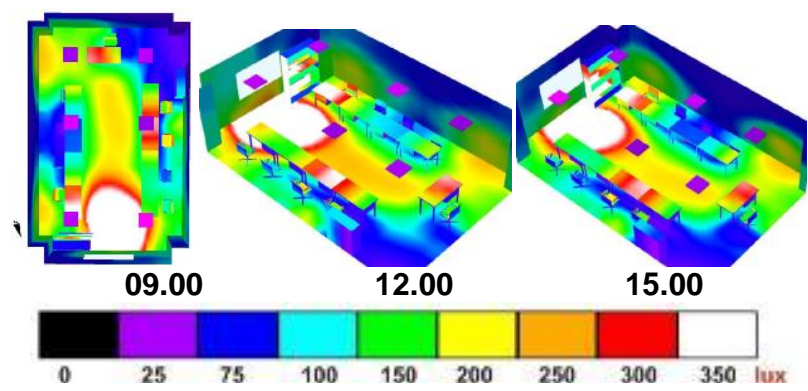

Gambar 20. False Colour Rendering Simulasi Dialux 10.1 Zona 3 Overcast Sky

Hasil simulasi memperlihatkan bahwa Tingkat pencahayaan integrasi eksisting pada Zona-3 hari Rabu tgl. 8 Mei 2013 dengan kondisi langit 
mendung belum memenuhi standarisasi, iluminasi rata-rata (Eavg) berkisar 174-189 Lux, yang berarti dibawah standar 350 Lux.

\section{Pencahayaan Integrasi Zona-4}

Tabel 4. Data pengukuran zona-4

\begin{tabular}{cccl}
\hline \multirow{2}{*}{ NO. } & \multirow{2}{*}{ WAKTU } & NILAI ILUMINASI (LUX) & $\begin{array}{l}\text { KONDISI } \\
\text { LANGIT }\end{array}$ \\
\cline { 3 - 4 } & & Eavg & \\
\cline { 3 - 4 } 1 & \multirow{2}{*}{09.00} & 1100 & CERAH \\
& & 1606 & BERAWAN \\
& & 579 & MENDUNG \\
2 & \multirow{2}{*}{12.00} & 822 & CERAH \\
& & 1249 & BERAWAN \\
& & 735 & MENDUNG \\
3 & \multirow{2}{*}{15.00} & 702 & CERAH \\
& & 1065 & BERAWAN \\
& & 576 & MENDUNG \\
\hline
\end{tabular}

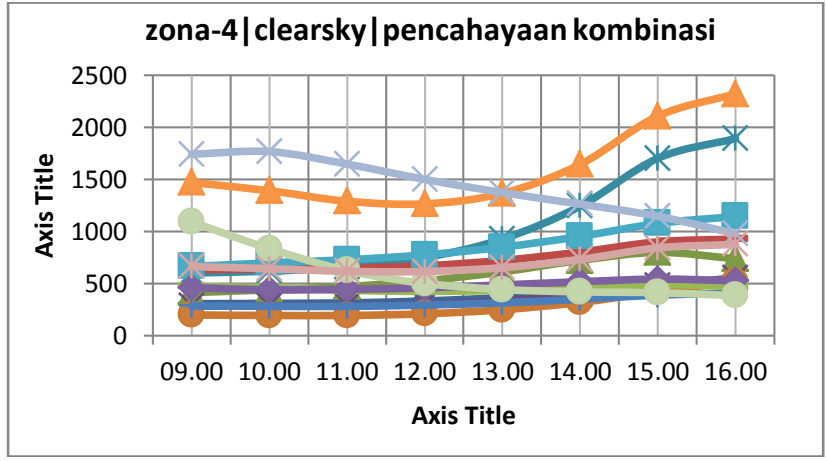

Gambar 21. Grafik Simulasi Pencahayaan Zona-4 pada Cuaca Cerah

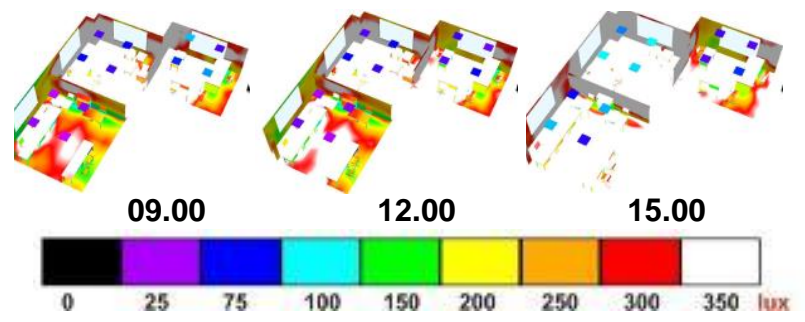

Gambar 22. False Colour Rendering Simulasi Dialux 10.1 Zona 4 Clear Sky

Hasil simulasi memperlihatkan bahwa Tingkat pencahayaan kombinasi manual pada Zona-4 (ruang sekretaris \& rg.data) hari Minggu tgl. 20 April 2013 dengan kondisi langit cerah memenuhi standarisasi, iluminasi rata-rata (Eavg) diatas standar lluminasi ruang Kerja yaitu 350 Lux. Tetapi pada Zona-4 ruang Staff Sekretariat belum memenuhi standarisasi.

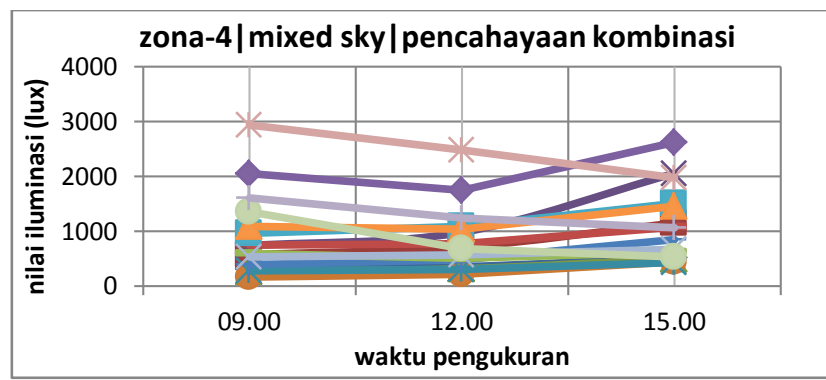

Gambar 23. Grafik Simulasi Pencahayaan Zona-4 pada Cuaca Berawan

Hasil simulasi memperlihatkan bahwa Tingkat pencahayaan kombinasi manual pada Zona-4 hari Minggu tgl. 26 Mei 2013 dengan kondisi langit berawan memenuhi standarisasi pada keseluruhan ruang, karenakan iluminasi diatas standar 350 Lux.
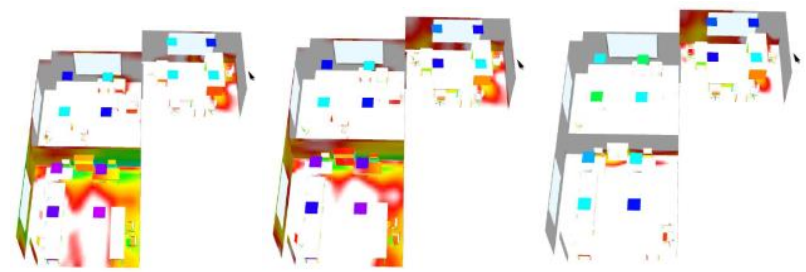

09.00

12.00

15.00

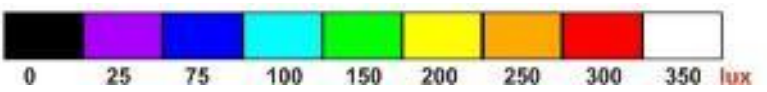

Gambar 24. False Colour Rendering Simulasi Dialux 10.1 Zona 4 Mixed Sky

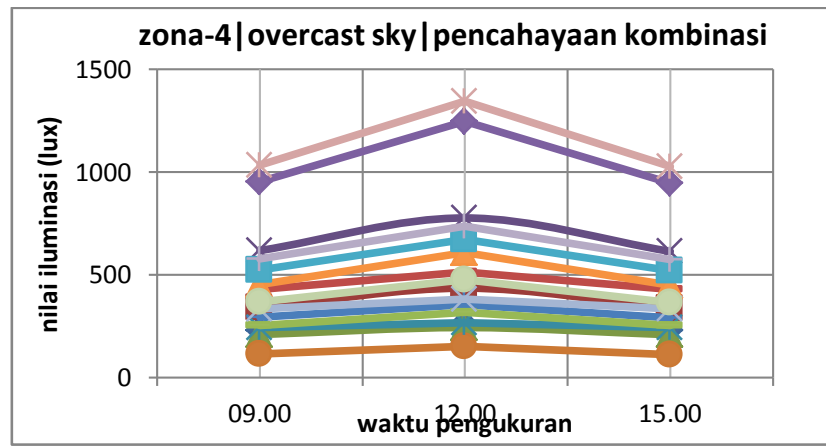

Gambar 25. Grafik Simulasi Pencahayaan Zona-4 pada Cuaca Mendung

Hasil simulasi memperlihatkan bahwa Tingkat pencahayaan kombinasi manual pada Zona-4 
hari Minggu tgl. 08 Mei 2013 dengan kondisi langit mendung memenuhi standarisasi pada Ruang Sekretaris dan Ruang Data, karenakan iluminasi diatas standar ruang Kerja 350 Lux. Tetapi pada ruang Staff belum memenuhi standar.

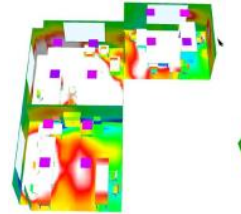

09.00

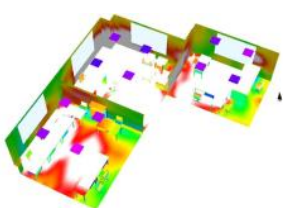

12.00

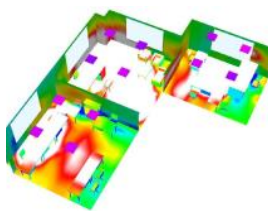

15.00

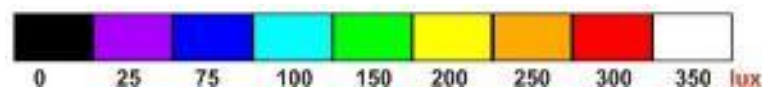

Gambar 26. False Colour Rendering Simulasi Dialux 10.1 Zona 4 Overcast Sky

\section{Pencahayaan Integrasi Zona-5}

Tabel 5. Data pengukuran zona-5

\begin{tabular}{cccccl}
\hline \multirow{2}{*}{ NO. } & \multirow{2}{*}{ WAKTU } & \multicolumn{3}{c}{ NILAI ILUMINASI (LUX) } & \multicolumn{1}{l}{$\begin{array}{l}\text { KONDISI } \\
\text { LANGIT }\end{array}$} \\
\cline { 3 - 6 } & & Emin & Emax & Eavg & \\
\hline \multirow{2}{*}{1} & \multirow{2}{*}{09.00} & 122 & 998 & 450 & CERAH \\
& & 97 & 1316 & 455 & BERAWAN \\
& & 71 & 1106 & 399 & MENDUNG \\
2 & \multirow{2}{*}{12.00} & 132 & 1169 & 488 & CERAH \\
& & 126 & 1343 & 505 & BERAWAN \\
& & 94 & 1512 & 500 & MENDUNG \\
3 & \multirow{2}{*}{15.00} & 216 & 1691 & 777 & CERAH \\
& & 211 & 2338 & 913 & BERAWAN \\
& & 71 & 1096 & 396 & MENDUNG \\
\hline
\end{tabular}

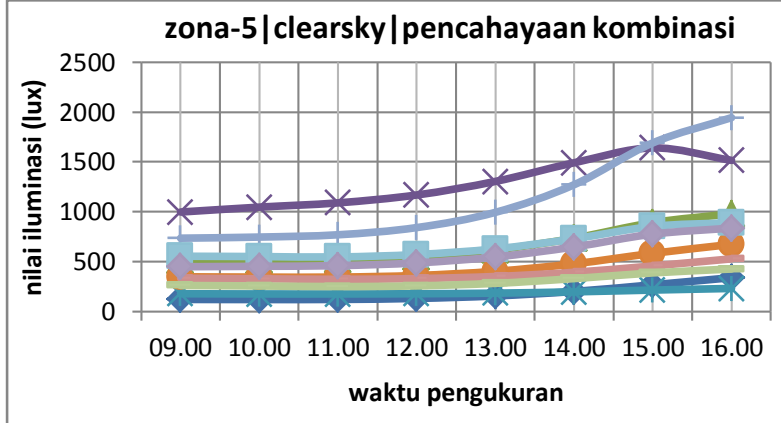

Gambar 27. Grafik Simulasi Pencahayaan Zona-5 pada Cuaca Cerah

Hasil simulasi memperlihatkan bahwa Tingkat pencahayaan integrasi eksisting pada Zona-5 tgl. 20 April 2013 dengan kondisi langit cerah memenuhi standarisasi, karenakan iluminasi rata-rata (Eavg) berkisar 488-777Lux, yang berarti diatas standar 350 Lux. Tetapi dapat dilihat penyebaran cahaya yang kurang merata, walaupun Eavg nya mencukupi.

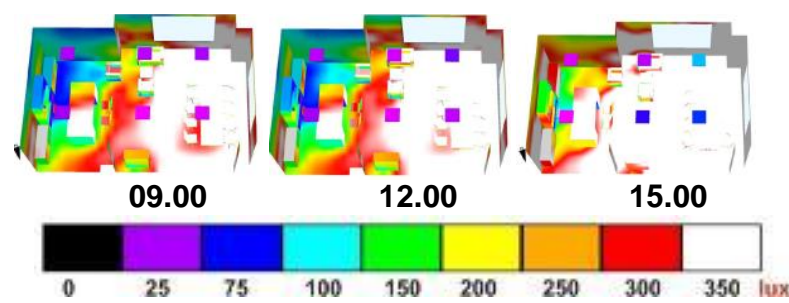

Gambar 28. False Colour Rendering Simulasi Dialux 10.1 Zona 5 Clear Sky

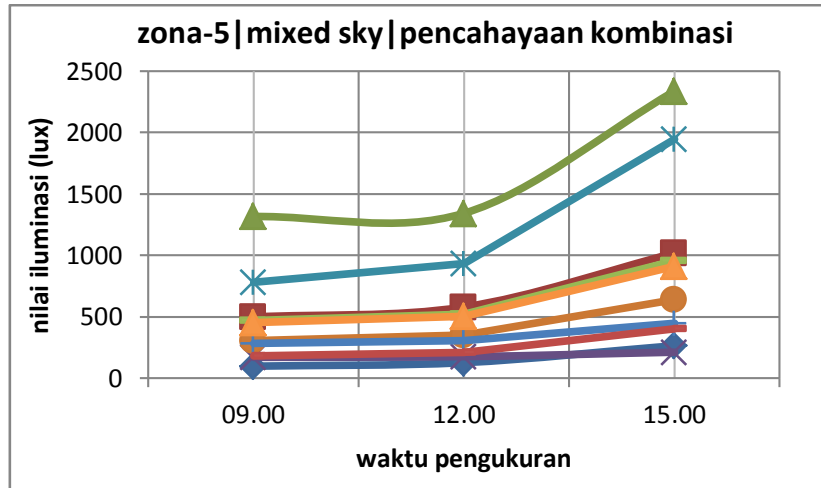

Gambar 29. Grafik Simulasi Pencahayaan Zona-5 pada Cuaca Berawan

Hasil simulasi memperlihatkan bahwa Tingkat pencahayaan kombinasi manual pada Zona-5 tgl. 26 Mei 2013 dengan kondisi langit berawan memenuhi standarisasi, iluminasi rata-rata (Eavg) berkisar 455-913 Lux, yang berarti diatas standar lluminasi ruang Kerja 350 Lux. Tetapi dapat dilihat penyebaran cahaya yang tidak merata, walaupun Eavg nya mencukupi.

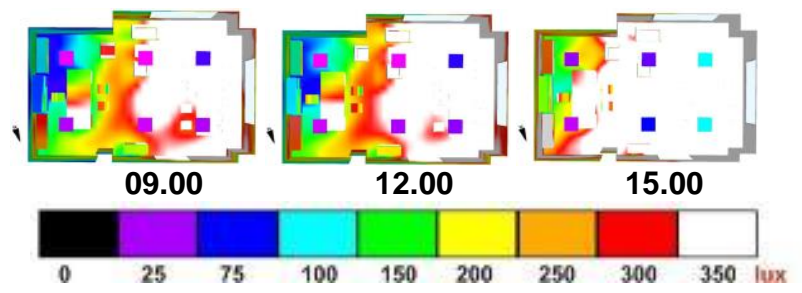

Gambar 30. False Colour Rendering Simulasi Dialux 10.1 Zona 5 Mixed Sky 


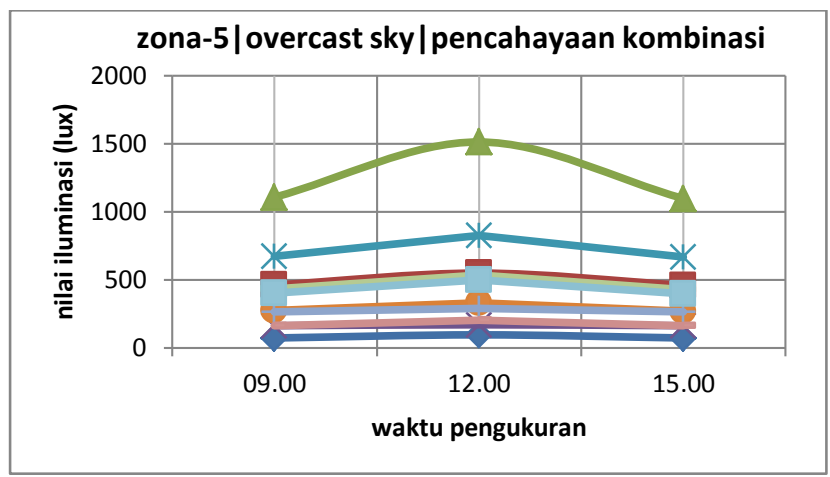

Gambar 31. Grafik Simulasi Pencahayaan Zona-5 pada Cuaca Mendung

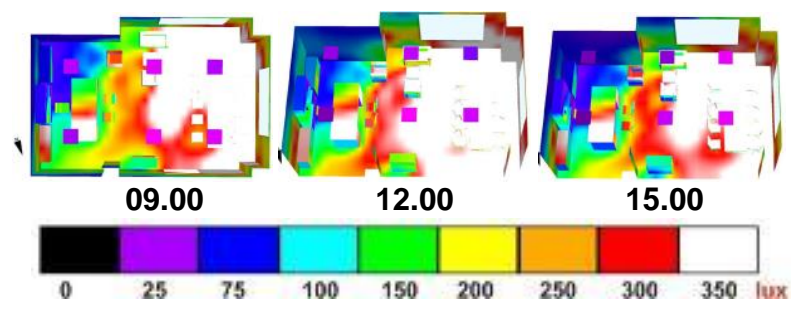

Gambar 32. False Colour Rendering Simulasi Dialux 10.1 Zona 5 Overcast Sky

Hasil simulasi memperlihatkan bahwa Tingkat pencahayaan kombinasi manual pada Zona-5 tgl. 8 Mei 2013 dengan kondisi langit mendung memenuhi standarisasi, dikarenakan iluminasi rata-rata (Eavg) berkisar 396-500 Lux. Tetapi dapat dilihat penyebaran cahaya yang kurang merata, walaupun Eavg nya mencukupi.

\section{Pencahayaan Integrasi Zona-6}

Tabel 6. Data pengukuran zona-6

\begin{tabular}{|c|c|c|c|c|c|}
\hline \multirow{2}{*}{ NO. } & \multirow{2}{*}{ WAKTU } & \multicolumn{3}{|c|}{ NILAI ILUMINASI (LUX) } & \multirow[t]{2}{*}{$\begin{array}{l}\text { KONDISI } \\
\text { LANGIT }\end{array}$} \\
\hline & & Emin & Emax & Eavg & \\
\hline \multirow{4}{*}{1} & & 33 & 294 & 165 & CERAH \\
\hline & 09.00 & 32 & 290 & 166 & BERAWAN \\
\hline & & 25 & 228 & 143 & MENDUNG \\
\hline & & 26 & 249 & 151 & CERAH \\
\hline \multirow[t]{3}{*}{2} & 12.00 & 28 & 241 & 148 & BERAWAN \\
\hline & & 26 & 238 & 146 & MENDUNG \\
\hline & & 28 & 249 & 152 & CERAH \\
\hline \multirow[t]{2}{*}{3} & 15.00 & 25 & 232 & 145 & BERAWAN \\
\hline & & 25 & 228 & 143 & MENDUNG \\
\hline
\end{tabular}

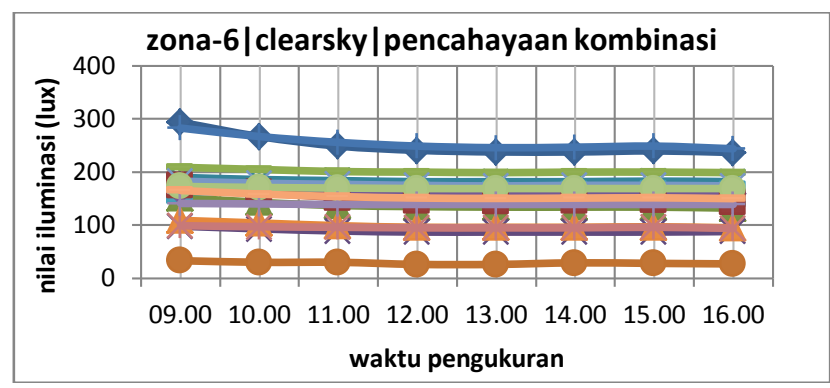

Gambar 33. Grafik Simulasi Pencahayaan Zona-6 pada Cuaca Cerah

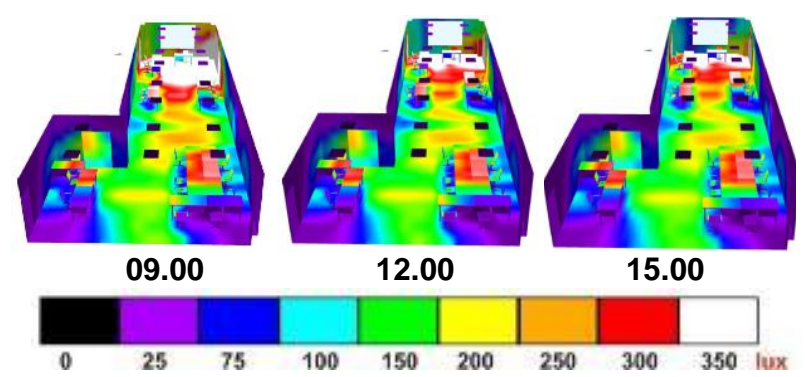

Gambar 34. False Colour Rendering Simulasi Dialux 10.1 Zona 6 Clear Sky

Hasil simulasi memperlihatkan bahwa Tingkat pencahayaan integrasi eksisting pada Zona-6 Hari Sabtu tgl. 20 April 2013 dengan kondisi langit cerah belum memenuhi standarisasi, dikarenakan iluminasi rata-rata (Eavg) hanya berkisar 151-165 Lux.

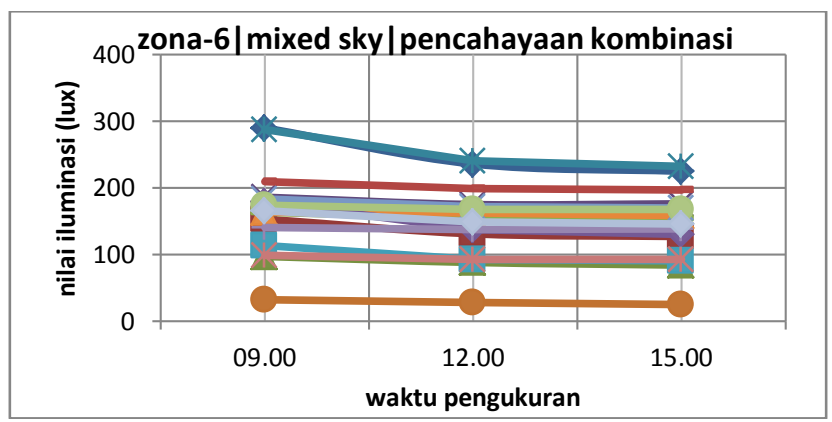

Gambar 34. Grafik Simulasi Pencahayaan Zona-6 pada Cuaca Berawan

Hasil simulasi memperlihatkan bahwa Tingkat pencahayaan kombinasi manual pada Zona-6 Hari Minggu tgl. 26 Mei 2013 dengan kondisi langit Berawan belum memenuhi standarisasi, dikarenakan iluminasi rata-rata (Eavg) hanya 
berkisar 145-166 Lux, yang berarti dibawah standar lluminasi ruang Kerja 350 Lux.

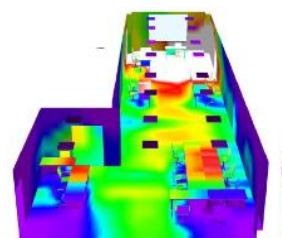

09.00

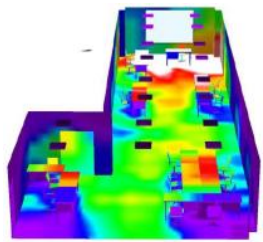

12.00

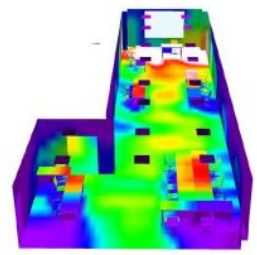

15.00

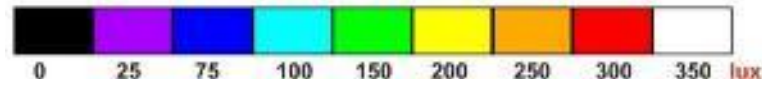

Gambar 36. False Colour Rendering Simulasi Dialux 10.1 Zona 6 Mixed Sky

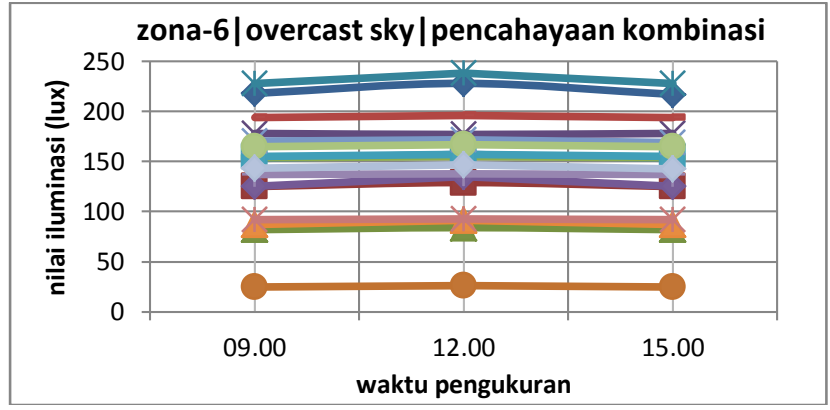

Gambar 37. Grafik Simulasi Pencahayaan Zona-6 pada Cuaca Mendung

Hasil simulasi memperlihatkan bahwa Tingkat pencahayaan kombinasi manual pada Zona-6 Hari Rabu tgl. 08 Mei 2013 dengan kondisi langit mendung belum memenuhi standarisasi, iluminasi rata-rata (Eavg) hanya berkisar 143146 Lux, yang berarti dibawah standar lluminasi ruang Kerja 350 Lux.

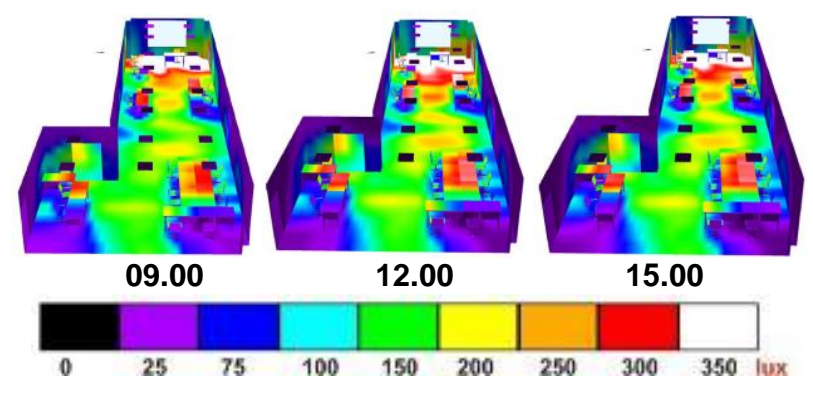

Gambar 38. False Colour Rendering Simulasi Dialux 10.1 Zona 6 Overcast Sky

\section{KESIMPULAN DAN SARAN}

Rata-rata Tingkat Pencahayaan Alami dari objek penelitian pada Kondisi Langit Cerah (Clearsky), Berawan (intermediate sky) dan Mendung (overcast sky), sudah hampir keseluruhan ruang memenuhi standarisasi Tingkat Pencahayaan Minimum (SNI 03-23962001) yaitu 350 Lux. Tetapi beberapa ruang terlihat belum dapat memenuhi standar lluminasi Ruang Kerja 350 Lux. Walaupun demikian, pada beberapa ruang yang telah memenuhi nilai lluminasi sesuai standar terlihat masih kurang pada pemerataan cahaya ruang (Uniformity of Light). Pada kondisi langit Mendung (Overcast Sky), rata-rata ruang masih belum memenuhi standarisasi, hanya dua ruangan yang dapat memenuhi standarisasi Tingkat Pencahayaan Minimum (SNI 03-23962001) yaitu 350 Lux.

Bantuan pencahayaan buatan (artificial lighting) yang diintegrasikan dengan pencahayaan alami masih perlu dikaji lagi, mengingat jangan sampai terjadi pemborosan energi listrik apabila tetap menggunakan pencahayaan buatan secara full. Untuk optimalisasi sistem pencahayaan integrasi, dapat ditambahkan lagi alat daylight sensor sebagai pengatur kebutuhan pencahayaan ruang dalam kondisi langit yang bervariatif, sehingga lampu yang menyala bisa lebih efektif.

Untuk lebih mengoptimalisasi lagi sistem pencahayaan integrasi alami-buatan, maka dapat mengganti jenis lampu yang lebih hemat energi, seperti lampu LED (Light Emitting Diode). Lampu jenis ini dapat menghemat sampai dengan $80 \%$ pemakaian energi listrik. 


\section{DAFTAR PUSTAKA}

Baharuddin. (2009). An Investigation of Factors Affecting Prediction of Daylight Avaibility in High-rise Residential Buildings in a-High-density Urban Environment (Disertasi). University of Hong Kong, China.

Belinda, Siti. (2012). Analisis Pencahayaan pada Ruang Ibadah Masjid Agung Al-Kautsar Kendari. Program Pascasarjana UNHAS. Makassar.

Evans, Benjamin. 1981. Daylight in Architecture, Architectural Record Book McGraw-Hill Book Company: New York.

Koeningsborger, et all. 1973. Manual of Tropical Housing and Building, Part One: Climatic Design. Orient Longman Limited: London.

Karlen, M, Benya, J. 2004. Lighting Design Basic: Dasar-Dasar Desain Pencahayaan. Terjemahan oleh Diana Rumagit. 2007. Erlangga: Jakarta.

Kristanto, Luciana. (2004). Penelitian terhadap Kuat Penerangan dan Hubungannya dengan Angka Reflektansi Warna Dinding, Studi Kasus Ruang Kelas Unika Widya Mandala Surabaya. Jurnal Dimensi Teknik Arsitektur Vol.32, No.1, Juli (2004):77-88

Nurdiah dkk. (2007). Pengaruh Lingkungan Penerangan Terhadap Kualitas Ruang pada Dua Tipe Ruang Kantor, Studi Kasus: Gedung Graha Pena. Prosiding Seminar Nasional PascasarjanaVII-2007 ISBN 979-545-0207-1.

Rahim, Ramli. (2000). Analisa Luminansi Langit dengan Metode Rasio Awan. Jurnal Dimensi Teknik Arsitektur Vol.28, No.2, Desember (2000):142146

Sukawi (2013). Kajian Optimasi Pencahayaan Alami pada Ruang Perkuliahan Studi Kasus Ruang Kuliah Jurusan Arsitektur FT UNDIP. Lanting Journal of Architecture, volume 2 , No.1, Februari (2013): $1-8$.

SNI 03-2396-2001: Tata Cara Perancangan Sistem Pencahayaan Alami pada Bangunan Gedung.

Widi, Restu Kartiko. 2010. Asas Metodologi Penelitian: Sebuah Pengenalan dan Penuntun Langkah Demi Langkah Pelaksanaan Penelitian. Graha Ilmu: Yogyakarta. 